\title{
How Consumers' Make Purchase Decisions with the Use of Reference Points
}

\author{
Theodore Tarnanidis $^{1^{*}} \quad$ Nana Owusu-Frimpong ${ }^{2} \quad$ Sonny Nwankwo ${ }^{3}$ \\ 1.School of Business Administration, University of Macedonia, GR-546 36, Thessaloniki, Greece \\ 2.School of Management studies, University of Professional Studies (UPSA) P.O.Box LG 149, Accra, Ghana \\ 3.Business School, University of East London, University Way, London, E16 2RD, United Kingdom \\ * E-mail of the corresponding author: tarnanidis@uom.edu.gr
}

\begin{abstract}
How consumers form their preferences has been triggered the notion of scientists as many internal and external influencing variables interact jointly during the decision-making process. One such influence variable is the use of consumer referents or reference points. Till today, the examination of reference hasn't been examined thoroughly from the domain of consumer decision-making process, as in the literature; there is a lack of research to examine the use of reference points in a wider variety of attributes, targeted to specific decision-making sequences. As such, the current research introduces a new approach on trying to examine the effects of reference points (RPs) on consumer buying decision process that rely on three time frame dimensions, ex-ante, ex-interium and ex-post. Most prior research on reference points from a consumer perspective has focused on the effects of possible prospects following the principles of what is called in the scientific community "prospect theory" or "mental accounting theory".The methodology that has been adopted is a case study analysis following the principles of Bayesian analysis that tries to bring out the effects of reference points in the consumer purchasing decision process. The results indicate that consumer' preferences of reference points are determined and structured during the whole buying decision process and can be altered according to potential signals and biased ways. These implications lead us to examine the laddering of RPs beyond the physical or tangible attributes. Knowledge of the consumers' assessment, about the use of the triangle framework of reference points, could be effectively used by different policy makers, in order to promote and guide consumers in a more efficient way. Therefore, several future avenues for casual modeling practice have opened.
\end{abstract}

Keywords: Reference Points, prospect theory, cognition, Bayesian Analysis

DOI: $10.7176 / \mathrm{JMCR} / 68-05$

Publication date:May $31^{\text {st }} 2020$

\section{Introduction}

In line with recent methodological advances from the behavioral economics and social psychology literature, researchers in the field of consumer behavior are trying in addressing the conscious and nonconscious shopping behavior of consumers, attitude formation, and behavioral judgment responses (Dimofte, 2010; Znanewitz et al., 2018). It can be argued that consumers are not always seeking absolute maximization over their choices, and they do not interpret the information presented on the decision tasks in terms of perceived positive or negative outcomes, like gains and losses (Van Osselaer, 2012; Babutsidze, 2007; McGraw et al., 2010; Jacoby et al., 1994; Stampfl, 1978; Chung -Hoon and Young-Gul, 2003; Holt, 1995). For example consumers connect their moods (e.g. happy/sad) with their preference judgments (Barone and Miniard, 2002; Sheth et al., 1991).

On the other hand, the stimuli of information which can be used should focus on the distinction of internal and external one (Babutsidze, 2007). The former are those that have been stored in memory from previous and past experiences. The latter include information that acquired during the decision process (Kinley et al., 2008). Through all these factors, consumers form their cognition, their attitudes and their preferences (Shah et al., 2016; Bettman and Zins, 1977; Simonson and Tversky, 1992; Payne et al., 1992).

One important question that has emerged from the literature is how do consumers anticipate with those factors and shape their buying preferences. Hence, this research will try to analyze the consumer buying decision process in terms of how it is being affected by the use of reference points (RPs) in different time conditions. The next section reviews the literature, followed by the research methodology, analysis and concluding remarks.

\section{Literature review}

The literature of cognition in marketing suggests that consumers evaluate and judge more easily the extrinsic cues, i.e. conscious parts of the brain, as opposed to intrinsic ones, i.e. non-conscious parts (Shah et al., 2016; Znanewitz et al., 2018). It was found that consumers do not have the tacit knowledge to evaluate all the intrinsic cues that surround a product bundle. Thus they seek to capture and identify different external cues that help them to structure their preferences. Specifically, the literature suggests these cues should include multiple categories of constructs that affect consumer perceptions when making product decision-making evaluations, i.e. the knowledge that arises from past purchases, consumer goals and values. Alike the acquisition and the selection of products involves 
symbolic meanings to consumers that have a direct impact upon their own social image, identity and life (Radder, 2006; Oh and Fiorito, 2002 ;Arkes et al., 2007;Van Ravenzwaaij et al., 2014; Payne, 1976; Bettman and Park, 1980). With research practice in mind, we begin the analysis by getting an insight of the main inquiry that has been made on reference points by underlining the existing problems. It should be mentioned that the literature on the specific construct has been guided from the elaboration and development of prospect theory started from the work of Kahneman and Tversky (1979) and which has been placed as an alternative examination process to the principles of the existing utility theory (Bouchouicha and Vieider, 2017; Friedman and Savage, 1948; Shafir and Thaler, 2006; Staddon, 1992; Thaler, 2008; Tversky and Kahneman, 1986) where preferences of diverse choices violate the axioms of the expected theory (see also Thaler, 1980; Laibson and Zeckhauser, 1998; Kahneman, 2003). According to utility theory individuals are seeking absolute maximization of the educed expected value (Friedman and Savage, 1952). The expected value is derived upon the rationality of evaluating different choice alternatives and selecting the option that has the maximum diminishing return (Friedman and Savage, 1948). Accepting that in mind the principle of utility theory stands upon the absolute upper limit of choices and preferences (Shafir and Thaler, 2006). In contrast with prospect theory it is commonly argued that individuals do not stand upon those axioms; instead they make subjective evaluations which can be regarded as irrational behavior (Tversky and Kahneman, 1986; Devetag, 1999). More plausibly preferences are structured with relevance to a reference point, which has disproportionately outcomes on the impact of sensed gains and losses (e.g. Mayhew and Winer, 2002). Furthermore, it could be stated that consumers have time-inconsistent preferences that are being restricted by self structured heuristics and regularities that arise from social and self-interest considerations (Huang, 2009; Tversky and Kahneman, 1986). Other researchers Laibson and Zeckhauser (1998) point out that the work of Amos Tversky and Daniel Kahneman has explained in general the inequalities on human judgments about the decisions, by spotting only externalities regarding their rationality, without giving any further explanations for the origins of those irregularities.

According to prospect theory on decisions yield under risk is assumed that consumers/people underweight or underestimate outcomes that are most probable as opposed to those that are obtained with certainty. The primary argument of prospect theory is that every decision can be examined as a choice between prospects (reference points), and ultimately framing those prospects or violating them by anchoring them differently, and so one can exert more reliable solutions. For example, actors are placed on bounded rationality problems by using several views and distinct preferences, like the gambling effect (losses, profits). The findings of prospect theory suggests that consumers are risk-seeking for losses, that are below the reference point and risk-averse for gains that are above the reference level. This implies that consumers are risk averse in choices that involve sure gains, and risk seeking in cases that involve sure losses. This is drawn in the following figure as an S-value mapping:

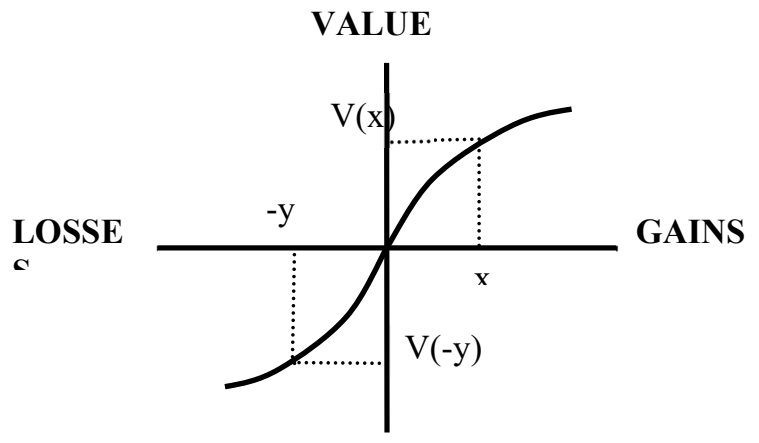

Figure 1. Prospect theory

The main two characteristic of the S-value function are the following:

(i) The value part is concave in the domain of gains $(<0, \mathrm{x}>0)$ and convex in the domain of losses $(>0, \mathrm{x}<0)$ and $\operatorname{losses}\left(U^{\prime \prime}(x)>0, \mathrm{x}<0\right)$ and

(ii) The value part is loss averse, steeper in the domain of losses (Kahneman and Tversky, 1979; Thaler, 1985; Kahneman, 1992).

For example, laboratory experiments (Kahneman and Tversky, 1979; Tversky and Kahneman, 1986) have shown that people absorb more disutility for a potential loss, than from a potential gain $(\mathrm{v}(\mathrm{x})<|\mathrm{v}(-\mathrm{x})| \mathrm{x}>0)$, i.e. the 'disutility' for losing $\$ 50$ exceeds the 'utility' of obtaining (gaining) the same amount of money (v $(50)<\mathrm{V}(-50)$ ). As well the S-value function follows the rules of diminishing sensitivity. For example the importance of the pleasure for moving from $\$ 50$ to $\$ 60$ is less, comparing with the movement from $\$ 5$ to $\$ 10$ (Heath et al., 1999). 
Mathematically, according to Thaler (1985) that kind of decision problems yield the following normative propositions:

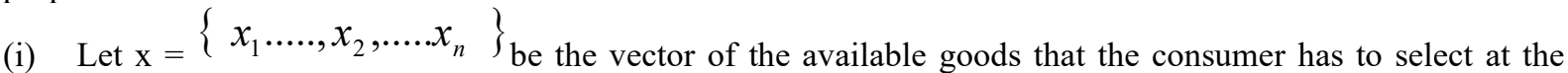
prices given $\mathrm{p}=\left\{p_{1} \ldots . ., p_{i}, \ldots . . p_{n}\right\}$, and

(ii) Have the utility function according to microeconomic theory be defined as $\mathrm{U}(\mathrm{x})$ and the potential expenditure income be defined as I.

Then the consumer maximization problem takes the form as:

$\max _{x} \sum_{\mathrm{U}(\mathrm{x}) \text { s. t. }} \sum p_{i} x_{i} \leq I$, with $x \geq 0, p \geq 0$ and the corresponding Lagrangean multiplier that can be solved, with the above first order conditions and complementary slackness one is: $\max _{x} \mathrm{U}(\mathrm{x})-\lambda\left(\sum p_{i} x_{i}-I\right)$. Likewise, Thaler (2008) in his research has examined the integration of aggregation effects, i.e. $v(x)+v(y)$ and segregation effects of reference points, i.e. $\mathrm{v}(\mathrm{x}+\mathrm{y})$. For example, "Mr. A was given tickets to two lotteries involving the World Series. He won $\$ 50$ in one lottery and $\$ 25$ in the other. Mr. B was given a ticket to a single, larger World Series lottery. He won $\$ 75$. Who was happier?" (Thaler, 1985, p. 203). The main point is that two segregate gains exert greater influence on the expectations to the actor, compared with a large equal gain. On the other hand, the opposite posits on the quadrant of losses (Thaler, 1985; Mellers, 2000). More analytically the value of $v(50)+v$ (25) is greater than $\mathrm{v}(75)$ and the value of $\mathrm{v}(-50)+\mathrm{v}(-25)$ is smaller than $\mathrm{v}(-75)$. To that extend, the work carried out by Thaler (2008) offers a more concrete analysis on compounding the labeling of gains and losses and the effects of segregation and desegregation (see table 1).

Table 1. Summary of Gains and Losses

\begin{tabular}{|c|c|c|c|}
\hline Case & Analysis & Outcome & Examples of Who is happier? \\
\hline 竞: & $\begin{array}{l}\text { Joint outcome }(\mathrm{x}, \mathrm{y}) \\
\text { Let } \mathrm{x}>0 \text { and } \mathrm{y}>0 \text {, then } \\
\mathrm{v}(\mathrm{x})+\mathrm{v}(\mathrm{y})>\mathrm{v}(\mathrm{x}+\mathrm{y})\end{array}$ & $\begin{array}{l}\text { Segregation is } \\
\text { preferred }\end{array}$ & $\begin{array}{l}\text { Mr. A was given tickets to two lotteries involving } \\
\text { the World Series. He won } \$ 50 \text { in one lottery and } \\
\$ 25 \text { in the other. } \\
\text { Mr. B was given a ticket to a single, larger World } \\
\text { Series lottery. He won } \$ 75 \text {. Who was happier? }\end{array}$ \\
\hline $\begin{array}{l}n \\
3 \\
3 \\
0 . \\
0 \\
0 \\
0 \\
0 \\
0 \\
0 \\
0 \\
0\end{array}$ & $\begin{array}{l}\text { Joint outcome }(-\mathrm{x},-\mathrm{y}) \\
\text { Let } \mathrm{x}>0 \text { and } \mathrm{y}>0 \text {, and } \\
\text { the outcomes }-\mathrm{x} \text { and }- \\
\mathrm{y} \text {, then } \\
\mathrm{v}(-\mathrm{x})+\mathrm{v}(-\mathrm{y})<\mathrm{v}(- \\
(\mathrm{x}+\mathrm{y}))\end{array}$ & $\begin{array}{l}\text { Integration is } \\
\text { preferred }\end{array}$ & $\begin{array}{l}\text { Mr. A received a letter from the IRS saying that } \\
\text { he made a minor arithmetical mistake on his tax } \\
\text { return and owed } \$ 100 \text {. He received a similar letter } \\
\text { the same day from his state income tax authority } \\
\text { saying he owed } \$ 50 \text {. There were no other } \\
\text { repercussions from either mistake. } \\
\text { Mr. B received a letter from the IRS saying that } \\
\text { he made a minor arithmetical mistake on his tax } \\
\text { return and owed } \$ 150 \text {. There were no other } \\
\text { repercussions from his mistake. }\end{array}$ \\
\hline 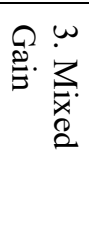 & $\begin{array}{l}\text { Joint outcome }(x,-y) \\
\text { Let } x>y \text {, then } \\
v(x)+v(-y)<v(x-y)\end{array}$ & $\begin{array}{l}\text { Integration is } \\
\text { preferred and } \\
\text { cancellation of } \\
\text { losses with larger } \\
\text { gains }\end{array}$ & $\begin{array}{l}\text { Mr. A bought his first New York State lottery } \\
\text { ticket and won } \$ 100 \text {. Also, in a freak accident, he } \\
\text { damaged the rug in his apartment and had to pay } \\
\text { the landlord } \$ 80 \text {. } \\
\text { Mr. B bought his first New York State lottery } \\
\text { ticket and won } \$ 20 \text {. }\end{array}$ \\
\hline $\begin{array}{l}+ \\
3 \\
3 \\
0 \\
0 \\
0 \\
0 \\
0 \\
0 \\
0\end{array}$ & $\begin{array}{l}\text { Joint outcome }(\mathrm{x},-\mathrm{y}) \\
\text { Let } \mathrm{x}<\mathrm{y} \text {, then } \\
\mathrm{v}(\mathrm{x})+\mathrm{v}(-\mathrm{y})</>\mathrm{v}(\mathrm{x}-\mathrm{y})\end{array}$ & $\begin{array}{l}\text { Segregate "Silver } \\
\text { Lining" principle }\end{array}$ & $\begin{array}{l}\text { Mr. A's car was damaged in a parking lot. He had } \\
\text { to spend } \$ 200 \text { to repair the damage. The same day } \\
\text { the car was damaged, he won } \$ 25 \text { in the office } \\
\text { football pool. } \\
\text { Mr. B's car was damaged in a parking lot. He had } \\
\text { to spend } \$ 175 \text { to repair the damage. } \\
\text { Or a similar example: } \\
\text { (Large loss, Small gain })=(\$ 40,-\$ 6000) \text {, then } \\
\text { segregation is preferred } \\
\text { (Small loss, Small gain) }=(\$ 40,-\$ 50) \text {, then } \\
\text { integration is preferred }\end{array}$ \\
\hline
\end{tabular}

We can say that the work of Thaler (2008) has introduced a new notion of "transaction Utility", that is expressed in two consummative processes, where a decision of approval or denial of a specific transaction is based upon the careful evaluation of each transaction. Later on, analogous multitude reframing examples have been 
employed by Thaler and Johnson (1990). They summarize that the integration effects depend on or can be moderated according to the perceived values of $\mathrm{X}$ and $\mathrm{Y}$, such that if losses can be attenuated by larger gains. It could be debated that one question that arises is the difficulty in anticipating how consumers reframe decision making problems and act in pragmatic situations, which is more naturalistic. Other researchers, i.e. Barkan et al. (2005), when investigating the puzzle of integration and segregation inside the process of planned and actual consumer choices have recognized the appearance of dynamic inconsistency biases. The authors found that people have more concrete knowledge about a specific product when they already acquire and possess it, instead of not acquiring it. Specifically, they refer to the so called "endowment effect", which its implications have been examined according to Kahneman and Tversky (1979) and Thaler (1980). In the axioms of gains and losses, they showed that decision makers have different judgments about a possible prospect, depending on the prior outcome of reference point. Moreover, Barkan et al. (2005) managed to expand previous related studies (see Barkan and Busemeyer, 2003; Tversky and Shafir, 1992), by identifying that people accept a second a gamble only when they know the outcome of the previous gamble (reference point). Whereas, Munro and Sugden (2003) criticize the endowment effect or status-quo bias, by underlining that reference points so far have been tested exogenously, which entails that they are given to decision makers, without examining possible discrepancies of other endogenous variables, such as customary or habitual consumption. Previously, Puto (1987), proposed a conceptual model of the buying decision framing process (see figure 2), where the existence of an initial reference point is influenced by: a set of expectations, a set of distinct buying intentions (objectives) and a final reference point.

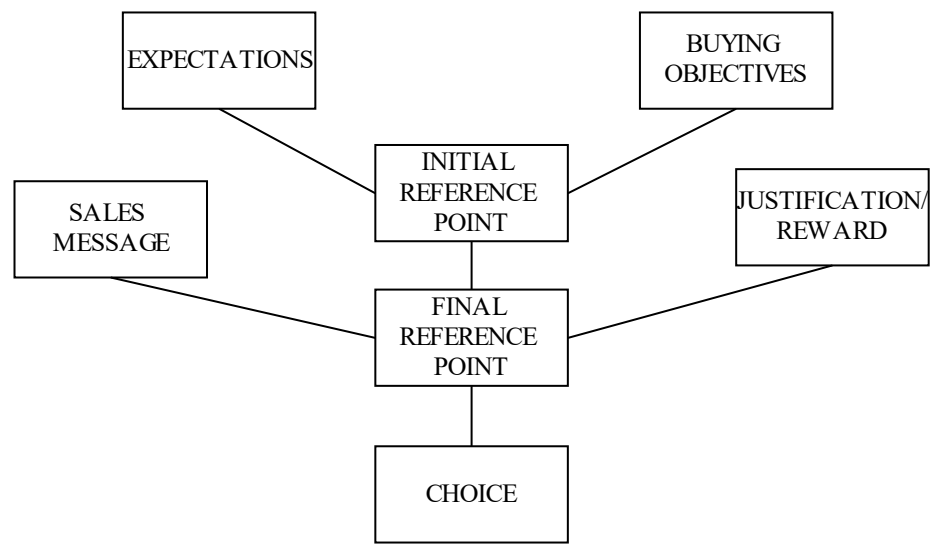

Figure 2. Reference points in the buying decision process

The authors noticed that the valence of expectations and buying objectives of consumers depend upon their past purchasing experience, i.e. when they have acquired a product before (low expectations) or not (higher expectations). However, the current framework is more applicable to specific buying cases, i.e. this framework has been produced in order to analyze the decision making procedure of industrial buyers, without offering justifiable generalizations to other settings. Bearing that in mind, Puto contends that the mapping of the initial reference point is portrayed on the mirror of the individual discrepancies that come from personality traits (styles) and other environmental variables.

In contrast, it is muted on analyzing the casualty of reference points (Rowe and Puto, 1987). The authors found that personality characteristics indirectly affect consumer choice in a consistent and articulated manner. Specifically, they have considered the impact of self-esteem in the formation of the initial reference point. They shaped and positively tested the theory that consumer with high self-esteem will get more challenging initial reference points, compared with low self-esteem consumers, which form less challenging initial reference points. Moreover, they found the same results for people who are, globally risk-averse and globally risk seeking. As an example, one can consider its own individual behavior in different contexts and situations, e.g. if a person is an extrovert and likes meeting new people, or make conspicuous shopping habits, then challenging reference points are used, and vice versa, in the case of an introvert person. Having that in mind, we can suppose that the formation of reference points is strongly been influenced, in a manner consistent with the way people think, act and behave globally (i.e. on their daily lives). Thus, consumers are most likely to search for additional information that will iterate and transform their initial reference points to a more concrete and reliable one that will ultimately become their final reference point that will become the actual decision frame.

The aforementioned premise has been previously examined by Kahneman and Tversky (1979) as risk averse to positive frames and risk seeking for negative frames. Whereas, Bettman et al. (1998) proposed that consumers often make decisions on the spot, and that they do not have well-structured existing preferences, but they develop them using a variety of constructive choice strategies (e.g. weighted added strategy, highest value strategy, lexicographic and elimination by aspects strategy). A suitable example of a constructive consumer decision task 
is the purchase of a car of different attributes (see table 2).

Table 2. Example car purchase

\begin{tabular}{|l|l|l|l|l|}
\hline Car & Reliability & Price & Safety & Horsepower \\
\hline A & Worst & Best & Good & Very poor \\
\hline B & Best & Worst & Worst & Good \\
\hline C & Poor & Very good & Average & Average \\
\hline D & Average & Poor & Best & Worst \\
\hline E & Worst & Very poor & Good & Best \\
\hline
\end{tabular}

Note: Attributes are scored on seven-point scales ranging from best to worst, with best indicating the most desirable value for the attribute and worst indicating the least desirable value

Analyzing this example, Kahneman and Tversky (1979) point that the same individuals can use different strategies in order to reach a final decision. This indicates that preferences are subject to information processing. Hence, as consumers acquire more information regarding a specific consumption, their initial preferences will be reformed and reshaped. In terms of the role of reference points we can say that consumers use multiple reference points simultaneously, so to build their final purchase judgments, i.e. attributes such as reliability only, or reliability versus cost, and price versus safety, etc. Also, Betts and Taran (2005) showed empirically that consumers are risk seeking below the average reference point, e.g. reliability of car brands, comparing with price or the opposite one. An identical example was carried out by Novemsky et al. (2007) where they found that consumers construct their choices during their buying process in terms of preference fluency. Analytically the authors have studied the influence of constructing a choice by making trade-offs among different attributes, and they concluded that the way that consumers process the fluency of information's (e.g. easy or difficult), activates salient interpretative mechanisms of cognition, which as a result form their evaluative judgments. On their research, they examined the fluency effects on choice outcomes, such as deferral or compromise (for a previous review see also the work of Dhar and Simonson, 2003). More recently, Busemeyer et al. (2007) provided a summary of the different models that are appropriate in analyzing consumer choices and decisions in terms of explaining the context effects.

The following table (table 3 ) analyzes the whole process of their research methodology and findings. Table 3. Analysis of context effects

\begin{tabular}{|c|c|c|c|c|c|c|}
\hline 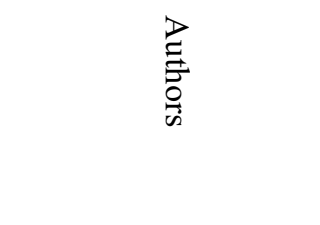 & $\begin{array}{l}\frac{3}{0} \\
\frac{0}{0} \\
\frac{0}{\infty}\end{array}$ & 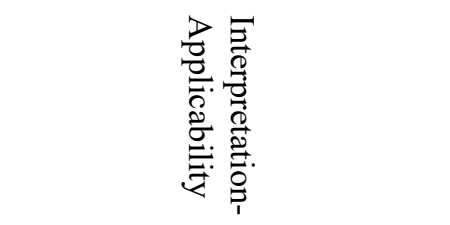 & 葛. & 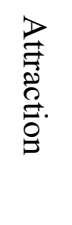 & 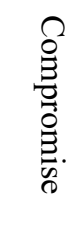 & 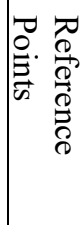 \\
\hline $\begin{array}{l}\text { Luce (1959) } \\
\text { Becker et al. (1963) } \\
\text { Harless and Camerer } \\
\text { (1994) } \\
\text { Hey and Orme (1994) }\end{array}$ & $\begin{array}{l}\text { Simple } \\
\text { Scalability }\end{array}$ & $\begin{array}{l}\text { Choices enclose a value utility } \\
\text { which is being described by a } \\
\text { probabilistic function, e.g. the } \\
\text { probability of choosing A, } \\
\text { among B or C, will be } \\
\text { increasing with the utility of A, } \\
\text { and will be decreasing with the } \\
\text { utilities of the other options. }\end{array}$ & No & Yes & No & $\mathbf{N o}$ \\
\hline $\begin{array}{l}\text { Thurstone (1959) } \\
\text { McFadden (1981) }\end{array}$ & $\begin{array}{l}\text { Random } \\
\text { Utility }\end{array}$ & $\begin{array}{l}\text { Choices enclose a value utility } \\
\text { which is being described by a } \\
\text { probabilistic function and is } \\
\text { deterministic, e.g. the } \\
\text { probability of choosing A, } \\
\text { among B or C, will be } \\
\text { increasing with the utility of A, } \\
\text { if and only is greater than the } \\
\text { sum of the other two, and vica } \\
\text { versa. }\end{array}$ & Yes & No & Yes & $\mathrm{No}$ \\
\hline $\begin{array}{l}\text { Tversky (1972) } \\
\text { Tversky and Sattath } \\
(1979)\end{array}$ & $\begin{array}{l}\text { Elimination } \\
\text { by aspects }\end{array}$ & $\begin{array}{l}\text { Each option initially has a } \\
\text { collection of aspects, and then } \\
\text { the most salient aspects are } \\
\text { dominating the others and } \\
\text { orderliness eliminating all the } \\
\text { others }\end{array}$ & Yes & No & No & $\mathbf{N o}$ \\
\hline
\end{tabular}




\begin{tabular}{|c|c|c|c|c|c|c|}
\hline 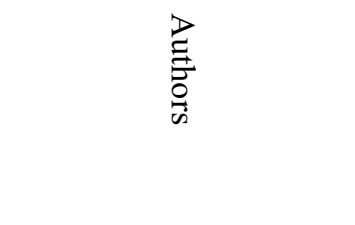 & $\frac{3}{0}$ & 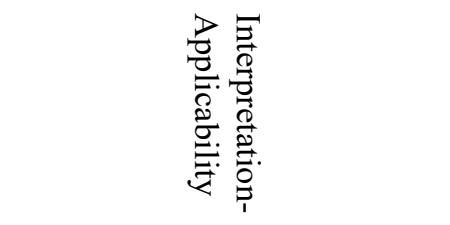 & 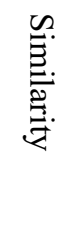 & 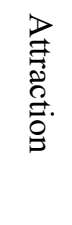 & 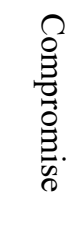 & 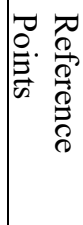 \\
\hline Payne et al. (1993) & $\begin{array}{l}\text { Strategy } \\
\text { Switching }\end{array}$ & $\begin{array}{l}\text { Compensatory versus non- } \\
\text { compensatory strategies, e.g. } \\
\text { each individual considers the } \\
\text { most important dimensions of } \\
\text { every choice (lexicographic } \\
\text { process) }\end{array}$ & Yes & No & No & No \\
\hline $\begin{array}{l}\text { Tversky and Simonson } \\
\text { (1993) } \\
\text { Tversky and Kahneman } \\
\text { (1991) } \\
\text { Tversky and Wakker } \\
\text { (1995) }\end{array}$ & $\begin{array}{l}\text { Componential } \\
\text { Context }\end{array}$ & $\begin{array}{l}\text { Suitable for context depended } \\
\text { preferences and choices that } \\
\text { are more than two. Measures } \\
\text { disadvantages and advantages } \\
\text { over options in terms of loss } \\
\text { aversion, where the formers } \\
\text { predominated the latter's. }\end{array}$ & No & Yes & Yes & Yes \\
\hline $\begin{array}{l}\text { Busemeyer and } \\
\text { Townsend (1993) } \\
\text { Roe et al. (2001) } \\
\text { Usher and McClelland } \\
(2004)\end{array}$ & $\begin{array}{l}\text { Decision } \\
\text { Field } \\
\text { Theory }\end{array}$ & $\begin{array}{l}\text { Preferences are analyzed over } \\
\text { time and they are context } \\
\text { depended, e.g. quality versus } \\
\text { price, or price versus brand } \\
\text { equity, and so forth. }\end{array}$ & Yes & Yes & Yes & Yes \\
\hline
\end{tabular}

Looking at the table it can be determined that the decision field theory can be used in order one to analyze the influence of different context effects on consumer purchasing decisions. For example the similarity effect on choices, has a positive impact for the superior option, by slighting the inferior one. Researchers state that decision field theory follows a sequential process where the more salient attributes or dimensions of a specific product, i.e. a home or a perfume, are considered first, and the decision is being held according to that opinion. At some other point in the scale of time, i.e. if persons have more time to analyze the less semantic attributes, then the decision options will vary. These examinations on choices are consistent with the previous work of other researchers (i.e. Busemeyer and Johnson, 2004; Diederich, 2003.

\subsection{Defining the concept of reference points}

Following the findings of the literature, we can say that a reference point is a neutral point of comparison against other objects (e.g. Helson, 1964; Thibaut and Kelley, 1959). Later on reference points have been determined as any stimuli that is related to other stimuli seen (Rosch, 1975). These early definitions according to Klein and Oglethorpe (1987) are vague, unclear, and misleading for the reason that it encompass multiple reference points in association to any stimulus. In relation to that, Kahneman and Tverky (1979) restructured this neutral point in conjunction with gains and losses. More recently, Zhang (2004) believes that reference points are those that have been formed by consumers through past and previous choices, and they act as a standpoint in the evaluation of current choice alternatives. Alike, Dholakia and Simonson (2005) and Tarnanidis et al. (2010; 2015) address the distinction of implicit (those that are used by consumers) and explicit reference points (those that are used by the seller or the advertiser) which is a continuum of retrospective and coherent existing theories (e.g. Beggan, 1994; Kahneman, 1992; Kahneman and Tversky, 1979; Mussweiler, 2003; Tversky and Kahneman, 1991) .

In particular, Dholakia and Simonson (2005) characterize reference points as implicit (those that are used by consumers) and explicit one (those that are used by the seller or the advertiser), and which both interact spontaneously or solely during the decision process. In their research they examined on-line bidding behaviors and they concluded that explicit reference points can have a thoughtful effect in explaining the flow of information that influence consumer buying behavior, as they manage to uncover more salient behaviors on how consumer's judgment is being made during an online buying process. They also found that explicit reference engenders to a more cautious and risk-averse behavior or and the purpose of comparisons can clement context effects and compromising. For example, they propose that vendors can use comparisons (with stronger brands or more judicious) as character points.

Analogous examination has been made by Tarnanidis et al. (2010) where they characterize reference points (RPs) as strong indicators of predicting consumer behavior. The authors believe that RPs can take the form of a single idea, a fact, an event, a person, or just different kinds of information. Alike, Tarnanidis et al. (2015) provided an examination on reference points based on two distinct dimensions, i.e. explicit and implicit referents (i.e. marketing variables and consumer personal variables), which in turn might shape consumer preferences. Therefore, 
it can be argued that reference points have been defined in a number of ways and this meditates its multifaceted nature.

After a careful assessment of the different definitions that exist in the literature on reference points, we believe that the most reliable are those that have been proposed by Rosch (1975), Dholakia and Simonson (2005) and Tarnanidis et al., 2010. As such, we define reference points as it follows: A reference point is an indicator or a stimulus that orients consumers to form their choices. This indicator originates from two sources. The first one comes from the marketing program of a Seller, and can be named as an "explicit reference point". The second one comes from the perspective of a consumer, and can be named as an "implicit reference point". Explicit reference points are those that clearly stated in the literature and can be summarized in the following categories: framing effects, product attributes, brand image, reference prices, store environment, promotion and advertising, salespeople, ethics, organizational culture, contracts, frequently loyalty programs, assortments and bundlings. Implicit reference points are those that implied in the literature and can be summarized as personal reference points (i.e. goals, hedonic and functional values, perceptions, personal identity, sensations, budget and time constrains, previous experiences, special occasions) and cultural reference points (i.e. reference groups, social values and norms, social class and social status).

\section{Methodology: Case study}

Moreover a similar consumer maximization problem can be solved via Bayes rule (Hirshleifer and Riley, 1992; Kihlstrom, 1984; Laffont, 1989). Consider the example that has been taken from the previous work of Simonson and Tversky (1992), where a consumer face the selection of three product alternatives of the same brand i.e. three different attributes such as quality of the same camera MINOLTA, which is illustrated at figure 3 . They proposed two principles that affect consumer buying decision, tradeoff contrasts and extremeness aversion. The authors have used the method of experiment by placing consumers to make decisions among alternative product characteristics (tradeoffs) like more favorable/ unfavorable (for example three types of VGA). Extremeness aversion was considering intermediate options.

They found that the same product appear more attractive on the background by using less favorable alternatives and visa-versa. In addition, they showed that the effects of contrast, applying on making tradeoffs amongst different product attributes. The extremeness aversion was an assimilation of prospect theory in examining middle option choices between tradeoffs of differences on version of quality and price. On the whole, consumers are more likely to be influenced by context effects if they make habitual purchases, as they do not have any established preferences.

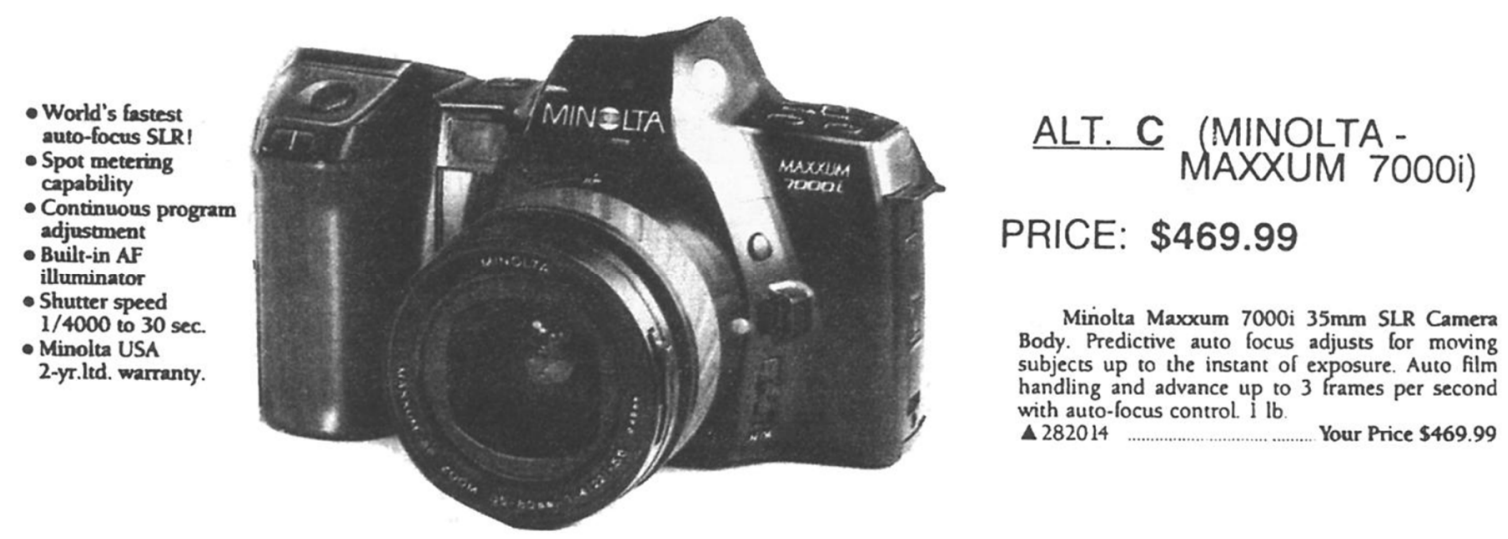



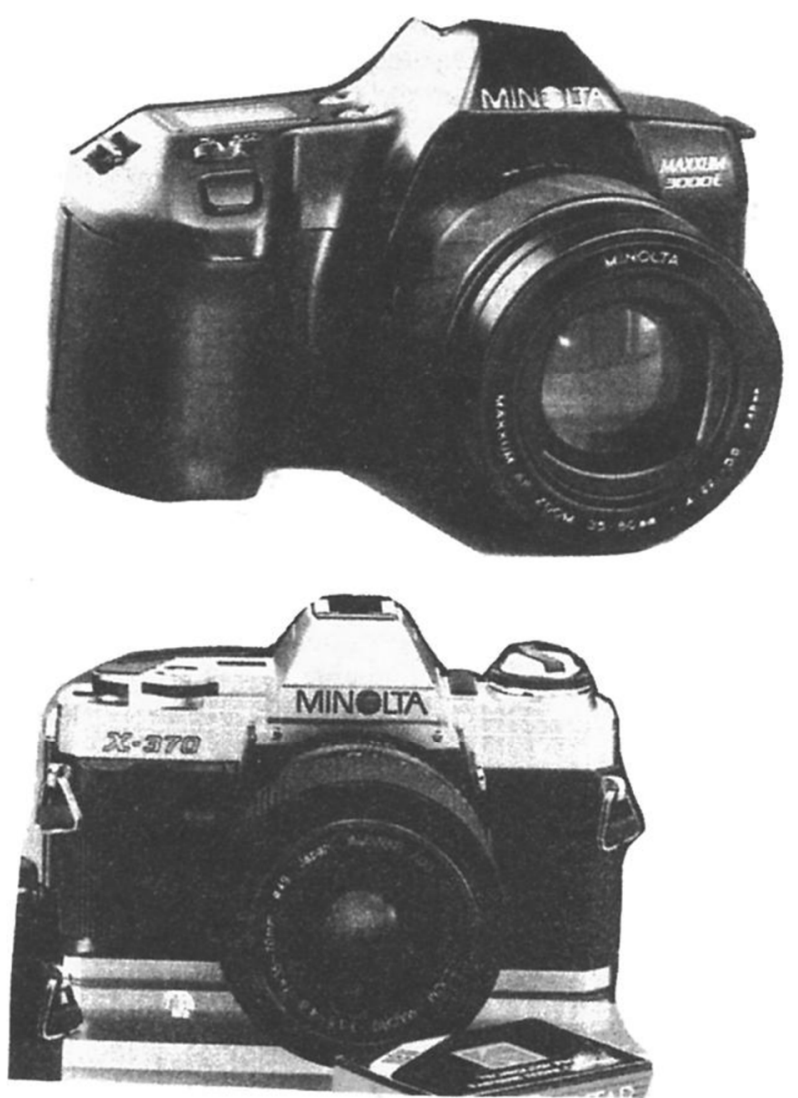

Source: Simonson and Tversky (1992, p.283)

Figure 3. Example of choice stimuli: $35 \mathrm{~mm}$ cameras

\section{Data Analysis via Bayes rule}

The possible explicit reference points accompanied with the three qualities are $\mathrm{Q}=\left\{q_{1}, q_{2}, q_{3}\right\}$. So, the consumer has to choose one of the three different qualities, which make different total prices $(\$ 469.99, \$ 239.99$, $\$ 169.99$ ). The outcome will be a buy or not buy decision. The problem can be solved alternatively by distinguishing three points in time:
Prior Beliefs/ implicit \&
Observed Beliefs/ implicit explicit reference points
$\&$ explicit reference points
Final Beliefs/ implicit \& explicit reference points

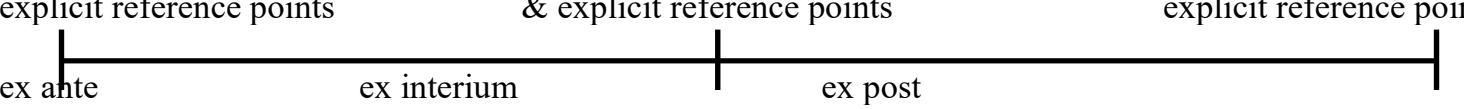

\section{ALT. A (MINOLTAX-370)}

\section{PRICE: \$169.99}

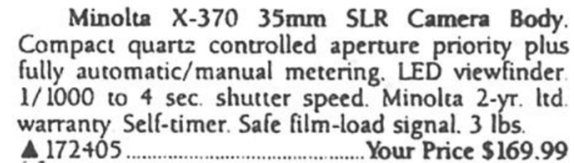

The decision maker is endowed with a priori-beliefs $\pi$ and a decision making, problem $(\mathrm{F}, \mathrm{Q}, \mathrm{B})$, that allows to change or update prior beliefs after of observation of the three different product attributes and reach the final decision of buy/not buy, ex-post. The conditional probability for a given signal of buy/not buy can be written w(q|b) and the Bayes equation is $\mathrm{w}(\mathrm{q} \mid \mathrm{b})=\frac{f(b \mid q) \pi(q)}{\pi_{f}(b)} \forall b \in B \forall q \in Q$, and $\pi_{f}(b):=\sum_{w \in Q} f(b \mid w) \pi(w)$, with $\pi_{f}(b)>0 \forall b \in B$ (no zero column)

- The state of the existing nature (explicit reference points) is $\mathrm{Q}=\left\{q_{1}, q_{2}, q_{3}\right\}$ and the three quality levels are

- Suppose that the observed beliefs (implicit/explicit
ALT. $\mathrm{C}=q_{1} \ldots .$. excellent quality

ALT. $\mathrm{B}=q_{2} \ldots .$. good quality

ALT. $\mathrm{A}=q_{3}$......bad /or medium quality

$q_{1} \ldots . . .90 \%$ willingness to buy 
reference points) of the consumer on buying a camera with the three attributes are: $q_{2} \ldots . . .40 \%$ willingness to buy

$q_{3} \ldots . .0 \%$ willingness to buy

- Whereas suppose that the prior ex ante beliefs (implicit/explicit reference points), were the following: ( $\pi$ $\left.\left(q_{1}\right), \pi\left(q_{2}\right) \pi\left(q_{3}\right)\right)=\left(\frac{6}{10}, \frac{3}{10}, \frac{1}{10}\right)$ or $(60 \%, 30 \%, 10 \%)$

- And the possible outcomes will be $\mathrm{B}=\left\{b_{1}, b_{2}\right\}=\{B u y$, NotBuy $\}$. The probability function is $\pi:[0,1]$

- The decision problem is $\mathrm{f}(\mathrm{q} \mid \mathrm{b})=1$ if $\mathrm{q}=\mathrm{b}$, or $\mathrm{f}(\mathrm{q} \mid \mathrm{b})=0$ if $\mathrm{q} \neq \mathrm{b}$

Now, at the stage of the observed beliefs the consumer sees the three different products which fragment his previous thoughts. This can be seen in the following matrix:

\begin{tabular}{l|l|l}
$\begin{array}{l}\text { Implicit Reference Points } \\
\text { States Q }\end{array}$ & \multicolumn{2}{|c}{\begin{tabular}{c}
\multicolumn{1}{|c}{ Explicit Reference Points signals B } \\
(not buy)
\end{tabular}} \\
\hline$q_{1}$ & $8 / 10$ & $2 / 10$ \\
\hline$q_{2}$ & $1 / 4$ & $3 / 4$ \\
\hline$q_{3}$ & 0 & 1
\end{tabular}

Using a Bayesian analysis the ex-ante reference points (prior beliefs) probabilities are:

$$
\begin{aligned}
& \pi_{f}\left(b_{1}\right)=\sum_{i=1}^{3} f\left(b_{1} \mid q_{i}\right) \pi\left(q_{i}\right)_{=8 / 10 * 6 / 10+1 / 4 * 3 / 10+0 * 1 / 10=0.555} \\
& \pi_{f}\left(b_{2}\right)=\sum_{i=1}^{3} f\left(b_{2} \mid q_{i}\right) \pi\left(q_{i}\right) \underset{=2 / 10 * 6 / 10+3 / 4 * 3 / 10+1 * 1 / 10=0.445}{ }
\end{aligned}
$$

Additionally the willingness to buy/not buy into one of the three quality categories is as follows:

$$
\begin{aligned}
& \mathrm{w}\left(q_{1} b_{1}\right)=\frac{f\left(b_{1} \mid q_{1}\right) \pi\left(q_{1}\right)}{\pi_{f}\left(b_{1}\right)}=\frac{8 / 10 * 6 / 10}{0.555} \approx 0.86 \\
& \mathrm{w}\left(q_{2} \mid b_{1}\right)=\frac{1 / 4 * 3 / 10}{0.555} \approx 0.135=0.14 \\
& \mathrm{w}\left(q 3 \mid b_{1}\right)=0 \\
& \mathrm{w}\left(q_{1} b_{2}\right)=\frac{2 / 10 * 6 / 10}{0.445} \approx 0.27 \\
& \mathrm{w}\left(q_{2} \mid b_{2}\right)=\frac{3 / 4 * 3 / 10}{0.445} \approx 0,505=0.5 \\
& \mathrm{w}\left(q^{3} b_{2}\right)=\frac{1 * 1 / 10}{0.445}=0.23
\end{aligned}
$$

We clearly can see that prior belief of implicit/explicit reference points $\pi(\cdot)=(0.6,0.3,0.1)$ to willingness of: Buy: $w\left(\cdot \mid b_{1}\right)=(0.86,0.14,0)$

Not Buy: $w(\cdot \mid b 2)=(0.27,0.50,0.23)$

This consumer is definitely willing to buy the camera that has excellent quality ( $86 \%)$, whereas the percentage of not buying a camera with good quality is $50 \%$. The main conclusion of this mathematical example is that the consumer prior to being exposed to the three VGA (explicit reference points) he/she was almost sure for purchasing the brand that offers excellent quality $(60 \%)$, as he had it as a reference point. Furthermore, our example gives new insights about how explicit reference points overlap with implicit in three different dimensions of time (exante, ex-interium and ex-post). The results are shown graphically in figure 4. 

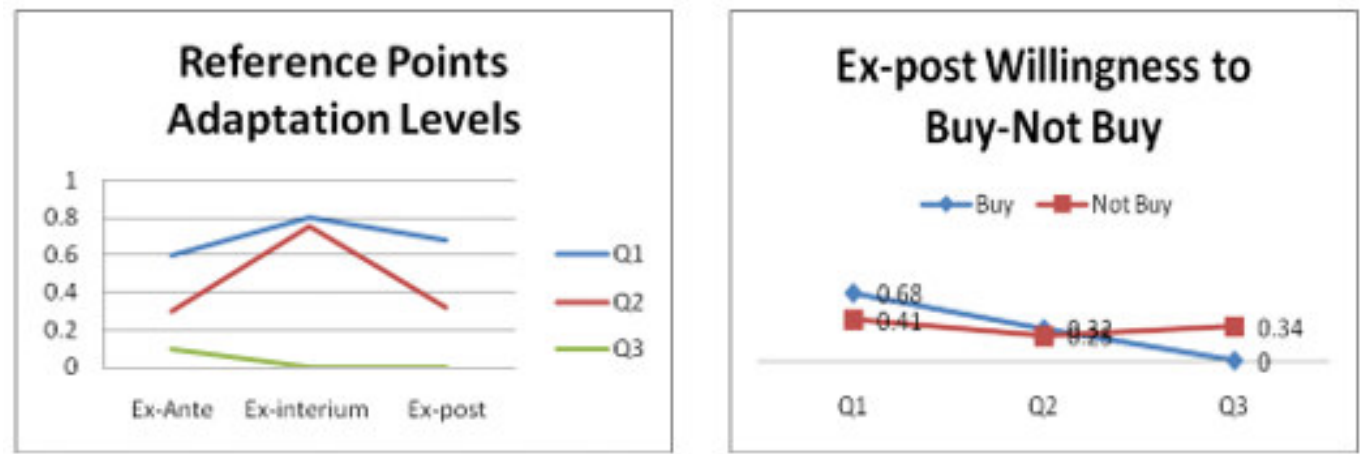

Figure 4. Update of reference points

The interpretation of constructs used for the final selection of implicit and implicit reference points is as follows:

- $\mathbf{A}:=$ ex-ante beliefs: implicit and explicit reference points that have been formed by the consumer prior to exposition of real time consumer making decision

- $\mathbf{B}:=$ ex-interium beliefs: implicit and explicit reference points that have been formed by the consumer during to exposition of real time consumer making decision

- $\mathbf{C}:=$ ex-post beliefs: implicit and explicit reference points that have been formed by the consumer after to exposition of real time consumer making decision

\section{Conclusion and recommendations}

According to our theoretical examination, scientists and managerial practitioners insofar followed the searching for reference point inside the axioms of "B" to "C" as a corner solution to explain the final evaluation of consumer decision-making outcomes. For example, in the current research the conceptual and methodological processes were examined mainly from the impacts of explicit reference points. Thus, our research proposes the searching of reference points through the linking of implicit referents. Having that in mind the experimental case study seeks to fill in that gap in the relevant literature review by trying to explain people's choices from the perspective of reference-dependence theories.

Finally, our proposed analysis via Bays rule, seeks to address multiple reference points, both implicit and explicit one, into the crafting of multicriteria decision-making problems that act upon the different time/conditions. Consequently, future scientists should try to spread out the casual modeling of our effort with other empirical case studies that examine the salient impacts of implicit reference points. More specifically, our triangle analysis for the searching of reference points can be used in the construction of different experimental settings (and/or scenarios) by acting as a supplementary methodology in the examination of marketing problems related to the assessment of different information for analyzing the cognitive behavior of consumers in such as when consumers engage in impulsive behaviors, or when they are pressured to rely on more automatic evaluation processes and automatic associations, in order to examine whether explicit and implicit reference point processes operate independently or in parallel fashion. Also, our model can be examined by different decision-makers in the building of marketing strategies (i.e. to analyze from the perspective of consumer's the settings of the marketing mix variables, let's say the advertising research may be seen in the effects of brief exposures to consumer products to ads that flash by on Web pages or other media. Additionally, as far as regards the product portfolio the implicit reference point's measures can be enriched by implementing other experimental surveys with the use of multicriteria decision-aid analysis (i.e. by the set of alternative weights).

Social psychologists and Neuro-marketers can examine the effects reference points on the consumer behaviors based on the modification of the brain, both anatomically and functionally, in response to the stimuli it receives from the environment which simply means that the brain does not stop changing. So the brain allows us with appropriate irritations to remodel it and teach it how to learn. Thus, when individuals are exposed continuously to a certain stimuli, then their brain starts an automatic learning process. Likewise, researchers may examine whether explicit and implicit processes operate independently or in parallel fashion with regards to the use of reference points across the three different time-frame conditions proposed.

What is more, a significant contribution would be the examination of the critical features that informs the construction of reference points in the mind of the consumer, and how judgment and decision-making process are updated across a time line from initial interest in a set of product to actually considering purchasing one of those products or how the alternatives are eliminated (i.e. from a psychological perspective - as compared to a formal perspective).

As a whole our analysis can be used in the examination of how consumers form their buying/purchase judgments based on the labeling of the information. For example, people (as consumers) tend to focus on 
positive/negative characteristics of the product, according to positive/negative valence of the messages. Also, consumers' form their product evaluations according to past and recent purchases, suggestions received from their close environment (i.e. peers, friends, and family) and on any other information they acquire during their efforts to structure their buying preferences. Therefore marketers could strengthen their marketing programmes by using those types of referents in order to measure and rank the impact of its specific category based on the reference points adaptation levels.

\section{References}

Arkes, H., Hirshleifer, D., Jiang, D., \& Lim, S. (2007). A cross-cultural study of reference point adaptation: Evidence from China, Korea, and the US. Organizational Behavior and Human Decision Processes, 112(2), 99-111.

Babutsidze, Z. (2007). How do consumers make choices? A survey of evidence. Journal of Economic Surveys, 26(4), 752-762.

Barkan, R., \& Busemeyer, J. R. (2003). Modeling dynamic inconsistency with a changing reference point. Journal of Behavioral Decision Making, 16, 235-255.

Barkan, R., Danziger, S., Ben-Bashat, G., \& Busemeyer, J. R. (2005). Framing reference points: the effect of integration and segregation on dynamic inconsistency. Journal of Behavioral Decision Making, 18, 213-226.

Barone, M. J., \& Miniard, P. W. (2002). Mood and Brand Extension Judgments: Asymmetric Effects for Desirable versus Undesirable Brands. Journal of Consumer Psychology, 12(4), 283-290.

Becker, G. M., Degroot, M. H., \& Marschak, J. (1963). Probabilities of Choices Among Very Similar Objects: An Experiment to Decide Between Two Models. Behavioral Science, 8(4), 306-311.

Beggan, J. K. (1994). The preference for gains in consumer decision making. Journal of Applied Social Psychology, 24(16), 1407-1427.

Bettman, J. R., \& Park, W. C. (1980). Effects of Prior knowledge and Experience and Phase of the Choice Process on Consumer Decision Processes: A Protocol Analysis. Journal of Consumer Research, 7, 234-248.

Bettman, J. R., \& Zins, M. A. (1977). Constructive Processes in Consumer Choice. Journal of Consumer Research, 4, 75-85

Betts, S. C., \& Taran, Z. (2005). Brand as reliability reference point: a test of prospect theory in the used car market. Journal of academy of business and economics, 5(1), 34-38.

Bouchouicha, R., \& Vieider, F. M. (2017). Accommodating stake effects under prospect theory. Journal of Risk and Uncertainty, 55(1), 1-28.

Busemeyer, J. R., Barkan, R., Mehta, C., \& Chaturvedi, A. (2007). Context effects and models of preferential choice: implications for consumer behavior. Marketing Theory, 7(1), 39-58.

Busemeyer, J. R., \& Johnson, J. G. (2004). Computational Models of Decision Making. In D. Koehler \& N. Harvey (Eds.), Handbook of Judgment and Decision Making (pp. 133-154). Oxford: Blackwell Publishing Co.

Busemeyer, J. R., \& Townsend, J. T. (1993). Decision Field Theory: A Dynamic Cognition Approach to Decision Making. Psychological Review, 100(3), 432-459.

Chung-Hoon, P., \& Young-Gul, K. (2003). Identifying key factors affecting consumer purchase behavior in an online shopping context. International Journal of Retail and Distribution Management, 31(1), 16-29.

Devetag, G. M. (1999). From utilities to mental models: A critical survey on decision rules and cognition in consumer choice. Industrial and Corporate Change, 8(2), 289-351.

Dhar, R., \& Simonson, I. (2003). The Effect of Forced Choice on Choice. Journal of Marketing Research, 40(May), 146-160.

Dholakia, U. M., \& Simonson, I. (2005). The effect of explicit reference points on consumer choice and online bidding behavior. Marketing Science, 24(2), 206-217.

Diederich, A. (2003). MDFT Account of Decision Making under Time Pressure. Psychonomic Bulletin and Review, $10(1), 157-166$

Dimofte, C. (2010). Implicit measures of consumer cognition. Psychology and Marketing, 27(10), 921-937.

Friedman, M., \& Savage, L. J. (1948). The Utility Analysis of Choices Involving Risk Journal of Political Economy, 56(4), 279-304.

Friedman, M., \& Savage, L. J. (1952). The expected-utility hypothesis and the measurability of utility. Journal of Political Economy, 60(6), 463-474.

Harless, D. W., \& Camerer, C. F. (1994). The Predictive Validity of Generalized Expected Utility Theories. Econometrica, 62(6), 1251-1289.

Heath, C., Larrick, R. P., \& Wu, G. (1999). Goals as reference points. Cognitive Psychology, 38, 79-109.

Helson, H. (1964). Adaptation level theory: An experimental and systematic approach to behavior New York: Harper.

Hey, J. D., \& Orme, C. (1994). Investigating Generalizations of Expected Utility Theories Using Experimental Data. Econometrica, 62(6), 1291-1326. 
Hirshleifer, J., \& Riley, J. G. (1992). The Analytics of Uncertainty and Information. Cambridge: Cambridge University Press.

Holt, D. B. (1995). How Consumers Consume: A Typology of Consumption Practices. Journal of Consumer Research, 22(1), 1-16.

Huang, J.-J. (2009). Revised Behavioural Models for Riskless Consumer Choice. The Journal of the Operational Research Society, 60(9), 1237-1243.

Jacoby, J., Jaccard, J. J., Currim, I., Kuss, A., Ansari, A., \& Troutman, T. (1994). Tracing the Impact of Item-byItem Information Accessing on Uncertainty Reduction. Journal of Consumer Research, 21(2), 291-303.

Kahneman, D. (1992). Reference Points, anchors norms and mixed feelings. Organizational Behavior and Human Decision Processes, 51, 296-312.

Kahneman, D. (2003). Maps of Bounded Rationality: Psychology for Behavioral Economics. American Economic Review, 93, 1449-1475.

Kahneman, D., \& Tversky, A. (1979). Prospect theory: An analysis of decision under risk. Econometrica, 47, 263291.

Kihlstrom, R. E. (1984). A 'Bayesian' exposition of Blackwell's theorem on the comparison of experiments. In Boyer M. \& R. E. Kihlstrom (Eds.), Bayesian models of economic theory (pp. 13-31). New York: Elsevier.

Kinley, T., Conrad, R., \& Brown, G. (2008). Personal vs. non-personal sources of information used in the purchase of men's apparel. Journal of Consumer Studies \& Home Economics, 24(1), 67-73.

Klein, N. M., \& Oglethorpe, J. E. (1987). Cognitive reference points in consumer decision making. Journal of Consumer Research, 14(1), 183-187.

Laffont, J. J. (1989). The Economics of Uncertainty and Information: MIT Press.

Laibson, D., \& Zeckhauser, R. (1998). Amos Tversky and Ascent of Behavioral Economics. Journal of Risk and Uncertainty, 16, 27-47.

Luce, R. D. (1959). Individual Choice Behavior: A Theoretical Analysis. New York: Wiley.

Mayhew, G. E., \& Winer, R. S. (1992). An empirical analysis of internal and external reference prices using scanner data. Journal of Consumer Research, 19(1), 62-70.

McFadden, D. L. (1981). Econometric Models of Probabilistic Choice. In C. F. Manski \& D. L. McFadden (Eds.), Structural Analysis of Discrete Data with Economic Applications (pp. 198-272). Cambridge, MA: MIT Press.

McGraw, A. P., Larsen, J. T., \& Kahneman, D. (2010). Comparing Gains and Losses. Psychological Science, 21(10), 1438-1445.

Mellers, B. A. (2000). Choice and the relative pleasure of consequences Psychological Bulletin, 126, 910-924.

Munro, A., \& Sugden, R. (2003). On the theory of reference dependent preferences. Journal of Economic Behavior and Organization, 50, 407-428.

Mussweiler, T. (2003). Comparison processes in social judgment: Mechanisms and consequences Psychological Review, 110(3), 472-489.

Novemsky, N., Dhar, R., Schwarz, N., \& Simonson, I. (2007). Preference fluency in choice. Journal of Marketing Research, 44(3), 347-356.

Oh, J., \& Fiorito, S. S. (2002). Korean women's clothing brand loyalty. Journal of Fashion Marketing and Management, 6(3), 206-222.

Payne, J. W. (1976). Task Complexity and Contingent Processing in Decision Making: An Information Search and Protocol Analysis. Organizational Behavior and Human Performance, 16, 366-387.

Payne, J. W. (1982). Contingent Decision Behavior. Psychological Bulletin, 92, 382-402.

Payne, J. W., Bettman, J. R., \& Johnson, E. J. (1992). Behavioral Decision Research: A Constructive Processing Perspective. Annual Review of Psychology, 43, 87-131.

Payne, J. W., Bettman, J. R., \& Johnson, E. J. (1993). The Adaptive Decision Maker. New York: Cambridge University Press.

Puto, C. P. (1987). The framing of buying decisions. Journal of Consumer Research, 14, 301-315.

Radder, L., Li, Y., \& Pietersen, J. (2006). Decision-Making Styles of Young Chinese, Motswana, and Caucasian Consumers in South Africa: An exploratory Study. Journal of Family Ecology and Consumer Sciences, 34, 20-31.

Roe, R. M., Busemeyer, J. R., \& Townsend, J. T. (2001). Mulitalternative Decision Field Theory: A Dynamic Connectionist Model of Decision Making. Psychological Review, 108(2), 370-392.

Rosch, E. (1975). Cognitive Reference Points. Cognitive Psychology, 7, 532-547.

Rowe, D., \& Puto, C. P. (1987). Do Consumers' Reference Points Affect Their Buying Decisions. In P. Anderson \& M. Wallendorf (Eds.), Advances in Consumer Research, (Vol. 14, pp. 188-192). Ann Arbor: MI: Association for Consumer Research.

Shafir, E., \& Thaler, R. H. (2006). Invest now, drink later, spend never: On the mental accounting of delayed consumption. Journal of Economic Psychology, 27, 694-712.

Shah, A. M., Eisenkraft, N., Bettman, J. R., \& Chartrand, T. L. (2016). “Paper or Plastic?”: How We Pay Influences 
Post-Transaction Connection. Journal of Consumer Research, 42(5), 688-708.

Sheth, J. N., Newman, B. I., \& Gross, B. L. (1991). Why we buy what we buy: A theory of consumption values. Journal of Business Research, 22(2), 159-170.

Simonson, I., \& Tversky, A. (1992). Choice in Context: Tradeoff Contrast and Extremeness Aversion. Journal of Marketing Research, 29(3), 281-295.

Staddon, J. E. R. (1992). Rationality, melioration, and law of effect models for choice. American Psychological Society, 3(2), 136-141.

Stampfl, R. W. (1978). Perceived risk and consumer decision making. Journal of Consumer and Home Economics, 2, 231-245.

Tarnanidis, T., Owusu-Frimpong, N., \& Marciniak, R. (2010). Consumer choice: between explicit and implicit reference points The Marketing Review, 10(3), 269-286.

Tarnanidis, T., Owusu-Frimpong, N., Nwankwo, S., \& Omar, M. (2015). Why we buy? Modeling consumer selection of referents Journal of Retailing and Consumer Services, 22(1), 24-36.

Thaler, R. H. (1980). Toward a Positive Theory of Consumer Choice. Journal of Economic Behavior and Organization, 1, 39-60.

Thaler, R. H. (1985). Mental accounting and consumer choice. Marketing Science, 4(3), 199-214.

Thaler, R. H. (2008). Mental accounting and consumer choice. Marketing Science, 27(1), 15-25.

Thaler, R. H., \& Johnson, E. J. (1990). Gambling with the house money and trying to break even: The effects of prior outcomes on risky choice. Management Science, 36, 643-660.

Thibaut, J. W., \& Kelley, H. H. (1959). The social psychology of groups. New York: John Wiley \& Sons.

Thurstone, L. L. (1959). The Measurement of Values. Chicago, IL: University of Chicago Press.

Tversky, A. (1972). Elimination by Aspects: A Theory of Choice. Psychological Review, 79(4), 281-299.

Tversky, A., \& Kahneman, D. (1986). Rational choice and the framing of decisions. Journal of Business, 59(4), $251-278$

Tversky, A., \& Kahneman, D. (1991). Loss aversion in riskless Choice: A reference-dependent model. Quarterly Journal of Economics, 106, 1039-1061.

Tversky, A., \& Sattath, S. (1979). Preference Trees. Psychological Review, 86(6), 542-573.

Tversky, A., Sattath, S., \& Paul, S. (1988). Contingent Weighting in Judgment and Choice. Psychological Review, 95(July), 371-384.

Tversky, A., \& Shafir, E. (1992). The disjunction effect in choice under uncertainty. Psychological Science, 3, 305-309.

Tversky, A., \& Simonson, I. (1993). Context Dependent Preferences. Management Science, 39, 1179-1189.

Tversky, A., \& Wakker, P. P. (1995). Risk Attitudes and Decision Weights. Econometrica, 63, 1255-1280.

Usher, M., \& McClelland, J. L. (2004). Loss aversion and inhibition in dynamical models of multialternative choice. Psychological Review, 111(3), 757-769.

Van Osselaer, S., \& Janiszewski, C. (2012). A Goal-BasedModel of Product Evaluation and Choice,. Journal of Consumer Research, 39(2), 260-292.

Zhang, F. Y. N. (2004). Role of reference points in consumer choice and product design: Bayesian methods and empirical tests. (PhD Dissertation), Cornell University.

Znanewitz, J., Braun, L., Hensel, D., Altobelli, C. F., \& Hattke, F. (2018). A critical comparison of selected implicit measurement methods. Journal of Neuroscience, Psychology, and Economics, 11(4), 249-266.

\section{Authors Affiliation:}

Theodore Tarnanidis, PhD., is a researcher in the Business Administration Department at the University of Macedonia. He finished his postdoctoral research at the University of Macedonia, in November 2015 in the area of sustainable entrepreneurship. He obtained a Ph.D. from the University of London Met., UK. He received his M.B.A from Liverpool University, UK and is a graduate from the University of Macedonia (Business Administration) and Alexander Technological Educational Institute (Marketing). His research focuses on Decision-Making Processes in Sustainable Innovations and Entrepreneurship, Conjoint Models and preference measurement techniques, modelling of purchases and consumer behavior. His work has been published in various internationally renowned scientific conferences and journals, mostly from the fields of Business Administration. Email: tarnanidis@uom.edu.gr

Nana Owusu-Frimpong, PhD., is a Professor of Marketing at University of Professional Studies, Accra (UPSA). Prior to his current role he was a Professor of Marketing at the Ghana Institute of Management and Public Administration (GIMPA) Business School and at the London Metropolitan University Business School, in England. He has published extensively in leading academic journals in the areas of financial/ services marketing, consumer behavior, international marketing, foreign direct investment in emerging markets and customer relations management. Email:owusufn@gmail.com

Sonny Nwankwo, PhD., is Emeritus Professor at the University of East London, UK, and the Provost of the 
Nigerian Defense Academy (NDA), Nigeria. He is Visiting Professor at universities across Africa, Australia, Europe, and North America. Prior to joining academia, he was a customer services manager in the telecommunications industry. He has published extensively in leading academic journals in the areas of consumer behavior, international marketing, marketing strategy and services marketing. E-mail: s.nwankwo@uel.ac.uk 